\title{
An Overview of the Performance of Public Infrastructure Megaprojects in Kenya
}

\author{
Austin Baraza Omonyo \\ Chief Consultant, Centre for Finance \& Project Management ${ }^{\mathrm{TM}}$ \\ Nairobi, Kenya
}

Doi: 10.19044/esj.2017.v13n35p78 URL:http://dx.doi.org/10.19044/esj.2017.v13n35p78

\begin{abstract}
The need for this study arose from the thesis that infrastructure megaprojects are often delivered over budget, behind schedule, with benefit shortfalls, over and over again. Many studies have been conducted towards this conclusion but these studies have not included Kenya which is increasingly adopting megaprojects as a model for delivering public goods and services. Through this quantitative study utilizing a cross-sectional census survey design, the performance of 27 completed public infrastructure megaprojects was assessed using broader measures of project success. The findings agree that these projects are delivered over budget and behind schedule but not with benefit shortfalls. It is also confirmed that process or project management success does not necessarily lead to product or organizational success. It is recommended that public infrastructure megaproject sponsors and implementers adopt project structures that allow for innovation through the use of advanced technology. Such structures should encourage the use of competitive tendering and a preference for pain/gain contractual arrangements to accommodate the differences in risk preferences between the client and the contractor, and to minimize the incidences of agency problem among the various stakeholders.
\end{abstract}

Keywords: Kenya, Megaproject, Performance, Success

\section{Introduction}

Megaprojects are usually large-scale, complex ventures that cost billions of money, take many years to develop and build, involve multiple public and private stakeholders, are transformational, and impact millions of people (Flyvbjerg, 2014). These projects are generally "greenfield" in nature as they often create new assets and utilize a variety of delivery models depending on their inherent complexity. In Kenya, megaprojects are increasingly used as the preferred delivery model for goods and services 
across a range of businesses and sectors such as, healthcare, infrastructure, water, energy and information technology. Such projects include the Ksh. 327 billion Standard Gauge Railway, the Ksh. 900 billion Konza techno-city, the Ksh. 2 trillion LAPPSET Corridor project, the Ksh. 5 billion Total War Against HIV/AIDS project and the Ksh. 30 billion Thika Superhighway, to mention but a few. These projects are often trait making since they are designed to ambitiously change the structure of society. This is in contrast with smaller and more conventional projects which are trait taking and they are designed to fit into pre-existing structures without modification (Hirschman, 1995).

Using the description by Flyvbjerg (2014), megaprojects are not just magnified versions of smaller projects but are a completely different breed of project in terms of their level of aspiration, lead times, complexity, and stakeholder involvement; implying that they are also a very different type of project to manage. These projects are also among the most complex category of project (Brady and Davies, 2014). Inherent complexity in megaprojects is the main source of contextual risk which is usually referred to as typological risk (Omonyo, 2015). The magnitude of this risk increases as we move from an environment of low complexity towards high complexity. The effectiveness of project control is usually affected by typological risk in such a way that as the value of the typological risk increases, exercising project control becomes more difficult. This could explain why complex megaprojects are usually delivered over budget, behind schedule, with benefit shortfalls, over and over again. Flyvbjerg (2011) characterizes this phenomenon as the "iron law" of megaprojects. The Project Management Institute, PMI (2011) documents projects such as the Boston Big Dig, Denver International Airport and the Sydney Opera House as examples of megaprojects that were delivered in conformity with the iron law of megaprojects. Flyvbjerg (2014) adds to this calamitous list several projects with the Egyptian Suez Canal reporting the greatest cost overrun of $1900 \%$, and notes that there is no end in sight for such overruns in megaprojects across the world.

In a study of 258 large scale transport infrastructure projects, Flyvbjerg, Holm and Buhl (2004) found that nine out of ten such projects have cost overruns; overruns of up to 50 percent in real terms are common, over 50 percent are not uncommon. In Africa, besides the Egyptian Suez Canal, the Chad-Cameroon Oil Pipeline project is reported to have been delivered at US\$ 4.2 billion up from its estimated cost of US\$ 3.7, and with huge benefit shortfalls (Bank Information Center-BIC, 2008). The Basilica of Our Lady of Peace of Yamoussoukro-Ivory Coast (which at the time of writing this article was the largest church in the world according to the Guinness Book of World Records) was originally estimated to cost US\$ 
300 million. This church was delivered at US\$ 360 million. Ironically, today the church is hardly half full (Shiferaw \& Klakegg, 2012). The Bujagali Falls 250 MW dam project in Uganda was originally estimated to cost US\$ 530 million but it was delivered in July 2012 at a cost of US\$ 900 million with huge benefit shortfalls (International Rivers, 2012).

Despite these data, the growth in the use of megaprojects to deliver public products, services and results in Kenya has been phenomenal over the past few years and there appears to be no end in sight for their use. Using the words of Flyvbjerg (2014), what we are witnessing is a consistent movement from megaprojects to giga projects and finally to tera projects (such as the LAPSSET Corridor project). In the Government of Kenya (2013) Medium Term Plan, infrastructure alone has been allocated Ksh. 7.5 trillion in project funding for a period of 5 years, more than twice the amount allocated to all the other foundations of national transformation.

Several studies have been carried out to establish the cause of the bizarre performance of infrastructure megaprojects but none of these studies has included Kenya in its sample of countries. This is despite the fact that the government of Kenya has had a consistent increase in the number of infrastructure megaprojects since 2002 . With about 31 such projects having been completed, and given the storyline of megaproject performance across the world, it is time to establish how successful these projects have been. The main question that this study seeks to answer is:

\section{Have public infrastructure megaprojects in Kenya been delivered successfully?}

For the remainder of this article, I present a note on measures of project success from which model measures are identified. This is followed with a description of the method and results from the study. Given that megaproject contractual arrangements have been shown to impact outcomes, this study includes a section linking performance with the various contract types applicable to the projects surveyed. A discussion of the results is then presented followed with conclusion and recommendation.

\section{Measures of Project Success}

Project success has received considerable attention within project management research literature over the last decades (Ika, 2009; Pinto \& Slevin, 1988b). This attention has enabled understanding of project success to evolve and reach maturity (Jugdev \& Muller, 2005). Indeed, there have been various attempts over the history of project management to define suitable criteria against which to anchor and measure project success (McLeod, Doolin \& MacDonell, 2012). The most recognized of these measures is the long established and widely used "iron triangle" of time, cost 
and quality (Atkinson, 1999; Cooke-Davies, 2002; de Wit, 1988, Ika, 2009; Jugdev, Thomas, \& Delisle, 2001).

However, the "iron triangle" dimensions are inherently limited in scope (Atkinson, 1999; Ika, 2009; Wateridge, 1998). A project that satisfies these criteria may still be considered a failure; conversely a project that does not satisfy them may be considered successful (Baccarini, 1999; de Wit, 1988, Ika, 2009). The "iron triangle" only focuses on the project management process and does not incorporate the views and objectives of all stakeholders (Atkinson, 1999; Baccarini, 1999; Bannerman, 2008; de Wit, 1988; Jugdev \& Muller, 2005; Wateridge, 1998).

Researchers have progressively widened the scope and constituency of what is meant by project success, recognizing that project success is more than project management success and that it needs to be measured against overall objectives of the project thus reflecting a distinction between the success of a project's process and that of its product (Baccarini, 1999; Markus \& Mao, 2004; Wateridge, 1998). Product success involves such criteria as product use, client satisfaction and client benefits (McLeod et al., 2012).

Researchers are also increasingly advocating for project success criteria that incorporates achievement of broader set of organizational objectives involving benefits to the wider stakeholder base (see Shenhar, Dvir, \& Levy, 1997; Shenhar, Dvir, Levy \& Maltz, 2001; Shenhar \& Dvir, 2007; Hoegl \& Gemuenden, 2001). This is plausible given that projects are a means of delivering the organization's strategic objectives. Proponents of this school of thought advocate for inclusion of success criteria such as business and strategic benefits.

Thus, project success is now regarded as a multidimensional construct, with interrelated technical, economic, behavioral, business and strategic dimensions (Bannerman, 2008; Cao \& Hoffman, 2011; Ika, 2009; Jugdev \& Muller, 2005; Jugdev, Thomas \& Delisle, 2001; Shenhar, Dvir, Levy \& Maltz, 2001; Thomas \& Fernandez, 2008). These enlarged measures of project success are ideal for measuring performance of megaprojects which in themselves are transformational and their choice is not just based on delivery of economic benefits but also technical, political and aesthetic appeal.

An important characteristic of megaprojects is that they are inherently complex. Several studies linking complexity with project success have confirmed that complexity predominantly determines project success (Meyer, 2014; Hargen \& Park, 2013; O’Donnell, 2010; Shermon, 2011, Flyvbjerg, Holm \& Buhl, 2004; Vanston \& Vanston, 2004). In the project environment, the complexity context is usually captured by the contractual arrangements. The type of contract used has a bearing on how risk is handled 
on the project and successful infrastructure megaprojects have tended to favor pain/gain contracts that apportion risk considerably. Such apportionment has been shown to increase the chances of delivery within budget and schedule (Brady \& Davies, 2014). There is also a raging debate on whether the use of outcome-based contracts could lead to better results when compared to behavior-based contracts.

Arising from the review of the developments in project success theory, this overview adopted the framework shown in Figure 1 to measure the success of public infrastructural megaprojects.

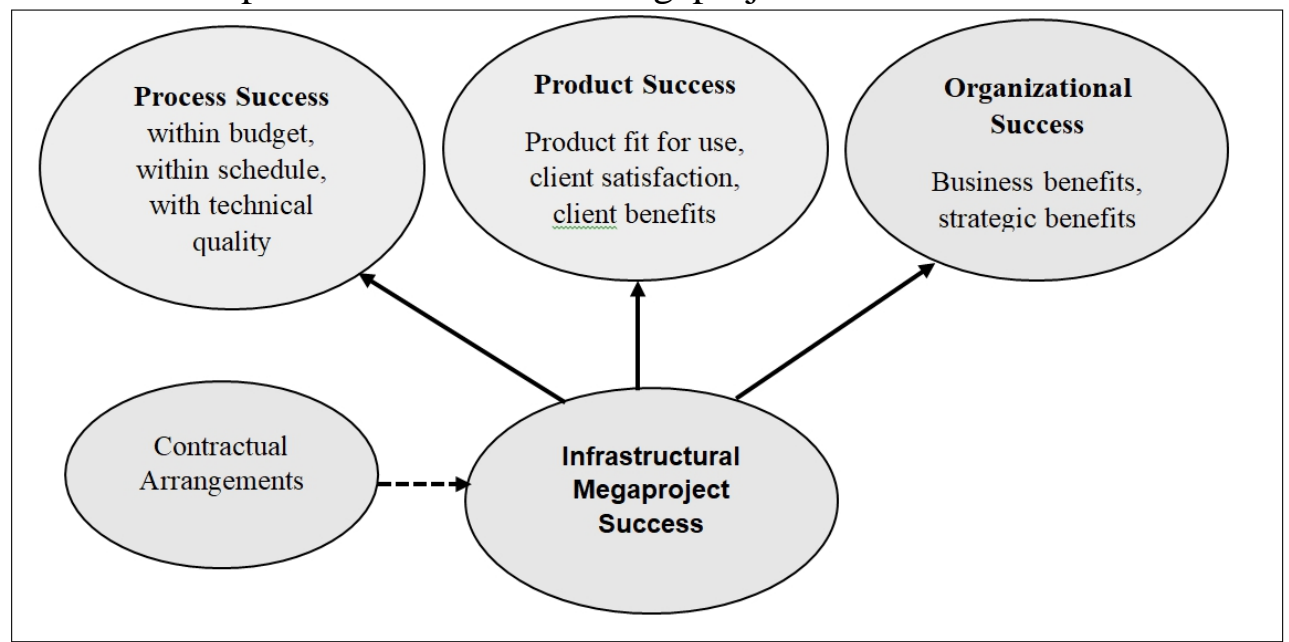

Figure 1: Conceptualization of Infrastructural Megaproject Success

\section{Method}

\section{Context and Design}

This study was operationalized through exploratory, descriptive and explanatory research goals based on Neuman (2003) classification of research goals. To achieve these goals, a post-positivist philosophy emphasizing virtual constructionist ontology (Gauthier \& Ika, 2012) was assumed. This philosophy utilizes both interpretivist (Bryman \& Bell, 2007) and pragmatist (Goldkuhl, 2012) epistemologies to generate knowledge based on a combination of deductive and inductive approaches. The choice of this philosophical perspective was guided by the social world of complex megaprojects. In this social world, complexity is the midpoint between order and disorder, and megaproject management is neither a practice nor a tool (as is the case with projects implemented in the modern social world) but a rallying rhetoric in a context of power play, domination and control (Gauthier \& Ika, 2012).

This study was designed to be quantitative and utilized a crosssectional census survey design to collect data. This design entails the collection of data (predominantly by questionnaire or structured interview) 
on usually quite a lot more than one case and at a single point in time in order to collect a body of quantitative or quantifiable data in connection with two or more variables, which are then examined to detect patterns of association (Bryman \& Bell, 2007).

\section{Population and Sample}

This study had as its primary population public sector infrastructural megaprojects implemented by the government of Kenya since 2005. Following Flyvbjerg (2014), the minimum budget for megaprojects included in this study was approximately Ksh. 1 billion. Managers, team members, sponsors and key stakeholders of these projects constituted the population of respondents from whom data was collected. A total of 31 projects were included in this study. For each project, four respondents comprising the project manager, project sponsor and two project team members were surveyed. In total, 108 respondents participated in this study.

\section{Instrument and Data Collection}

Fieldwork for this study utilized a project success questionnaire developed based on the works of Shenhar and Dvir (2001) and McLeod et al. (2012). Questionnaire survey is hailed to be an efficient data collection mechanism when the researcher knows exactly what is required and how to measure the variables of interest (Neuman, 2003). This questionnaire comprised 18 items blending open and closed ended questions on one part and Likert-type questions on the other part. The first part involving closed and open ended questions was meant to assess process success while the Likert-type questions assessed product and organizational success on a scale of 1 (strongly agree) to 5 (strongly disagree).

The first phase of data collection involved a pilot study on four projects to test the reliability and validity of the instrument. The results of the pilot study showed that the instrument was reliable with an overall internal reliability of 0.889 . This value is greater than the cut-off Cronbach's alpha of 0.7 (Nunnally, 1978). The pilot study results also demonstrated high concept, construct, and external reliability, in the study instruments. The second phase involved using revised study instrument to collect primary data from the remaining 24 projects.

\section{Data Analysis}

Collected data was processed and analyzed using Microsoft Access 2010, IBM's SPSS version 20 and Microsoft Excel 2010. Quantitative data analysis was conducted using both descriptive and inferential statistics. The main descriptive statistics used were the mean, standard deviation, coefficient of variation, indices, skewness, kurtosis and percentages. The 
inferential statistics used were Pearson correlation coefficients and tests of significance. Data presentation was largely through text, figures and tables.

\section{Results \\ Introduction}

A total of 27 completed infrastructural megaprojects, representing a response rate of $87.1 \%$, were surveyed as part of this research. Of these projects, 2 (7.4\%) were from Kenya Ports Authority, 2 (7.4\%) were from Kenya Pipeline Company, 6 (22.2\%) were from Kenya Airports Authority, 3 (11.1\%) were from Kenya Power and Lighting Company, 1 (3.7\%) was from Kenya Electricity Generating Company, 5 (18.5\%) were from Kenya Urban Roads Authority, 1 (3.7\%) was from Kenya Civil Aviation Authority, 1 (3.7\%) was from Geothermal Development Company, with the remaining 6 (22.2\%) coming from Kenya National Highways Authority.

All the projects surveyed had a budget at appraisal ranging from approximately Ksh. 1 Billion to Ksh. 40 Billion with 8 of these projects (29.6\%) having a budget at appraisal of over Ksh. 10 Billion. The scheduled duration for these projects ranged from 4 months to 72 months with most projects having a scheduled duration of above 20 months. The project locations were spread across several counties in Kenya. All the projects were turnkey, involving a variation of Engineer-Procure-Construct (EPC) and Design-Build-Transfer (DBT) delivery arrangements.

\section{Process Success}

Process success incorporates the traditional measures of efficiency (delivery within budget and time schedule) and quality. Efficiency was measured using the Cost Performance Index (CPI) and Schedule Performance Index (SPI) with the weighted average of these indices calculated to denote the overall efficiency index for the project. The CPI results show that $14(52 \%)$ projects were delivered over budget, 9 (33\%) projects were delivered on budget with the remaining 4 (15\%) being delivered under budget. The four sets of factors that were cited for budget overruns, in descending order of occurrence, are: scope changes (37\%); claims and penalties (22\%); currency fluctuation and inflation (22\%); and procurement issues (18.5\%). Figure 2 summarizes these causes of cost overrun.

The main factors cited for delivery on and under budget were competitive tendering (14.8\%) and use of imposed budgets $(7.4 \%)$. However, in all cases where imposed budgets were used, the project scope was narrowed to fit into the budget. The figure below summarizes the identified causes of cost overruns. 


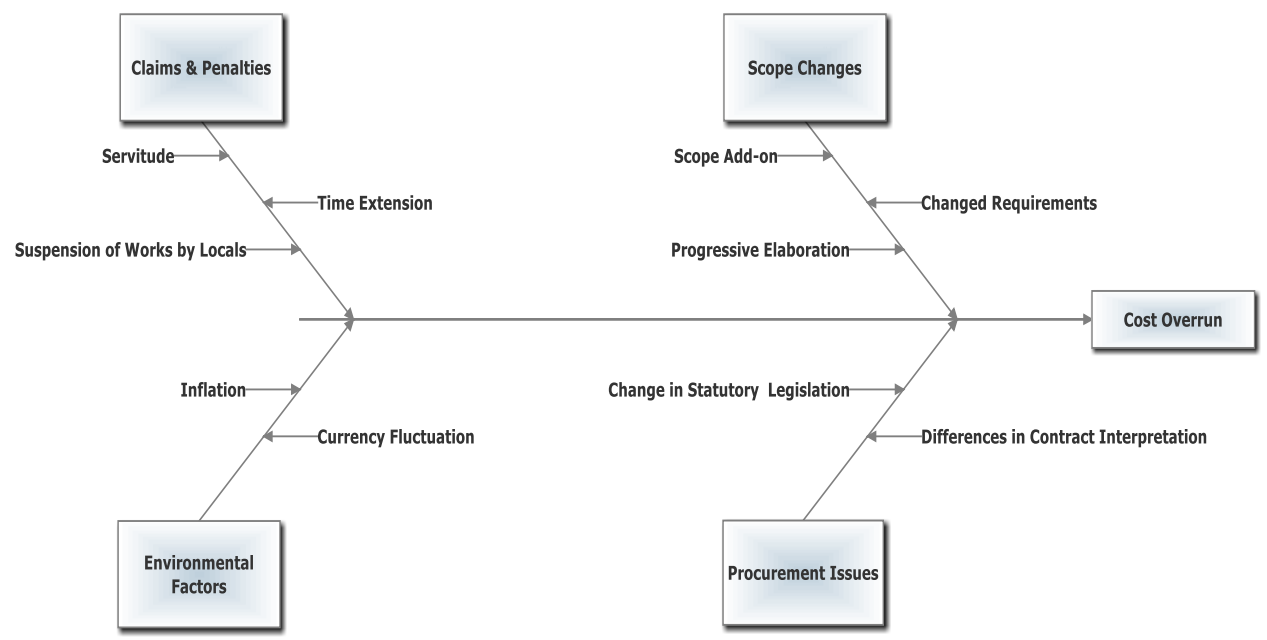

Figure 2: Major Causes of Cost Overrun

SPI results show that of the 27 megaprojects surveyed, $22(81 \%)$ were delivered behind schedule, $3(11 \%)$ were delivered on schedule while 2 (7\%) were delivered ahead of schedule. The five sets of factors that were cited for schedule overruns, in order of importance, are: environmental factors (48\%); stakeholder issues (36.8\%); scope changes (33\%); and procurement issues $(33 \%)$. The main factors that were cited for delivery on or ahead of schedule were: use of advanced technology (18\%) and inclusion of late delivery penalties in the contract (7\%). Figure 3 summarizes the causes of schedule delay.

Simple weighted averages of the CPI and SPI values were calculated to give the Weighted Project Efficiency (WPE) values for each project. Using these values, a total of $4(15 \%)$ megaprojects had efficiency levels greater or equal to $1(100 \%)$. The rest $(85 \%)$ of the megaprojects were delivered at efficiency levels lower than 100\%. The WPE measures for each of the 27 megaprojects were rated based on a predetermined scale in order to assign a score for project efficiency. The maximum score on this scale was 5 (WPE greater or equal to 1) and the lowest score was 1 (WPE is less or equal to 0.4 ). The results show that the 27 megaprojects had a mean of 0.91 in cost performance, 0.73 in schedule performance and 0.82 in overall efficiency. Combining these means with their standard deviations, analysis of the Coefficients of Variation values indicates that the schedule performance index had the highest relative variability $(\mathrm{CV}=0.35)$ compared to both cost performance index $(\mathrm{CV}=0.16)$ and overall efficiency index $(\mathrm{CV}=0.21)$. 


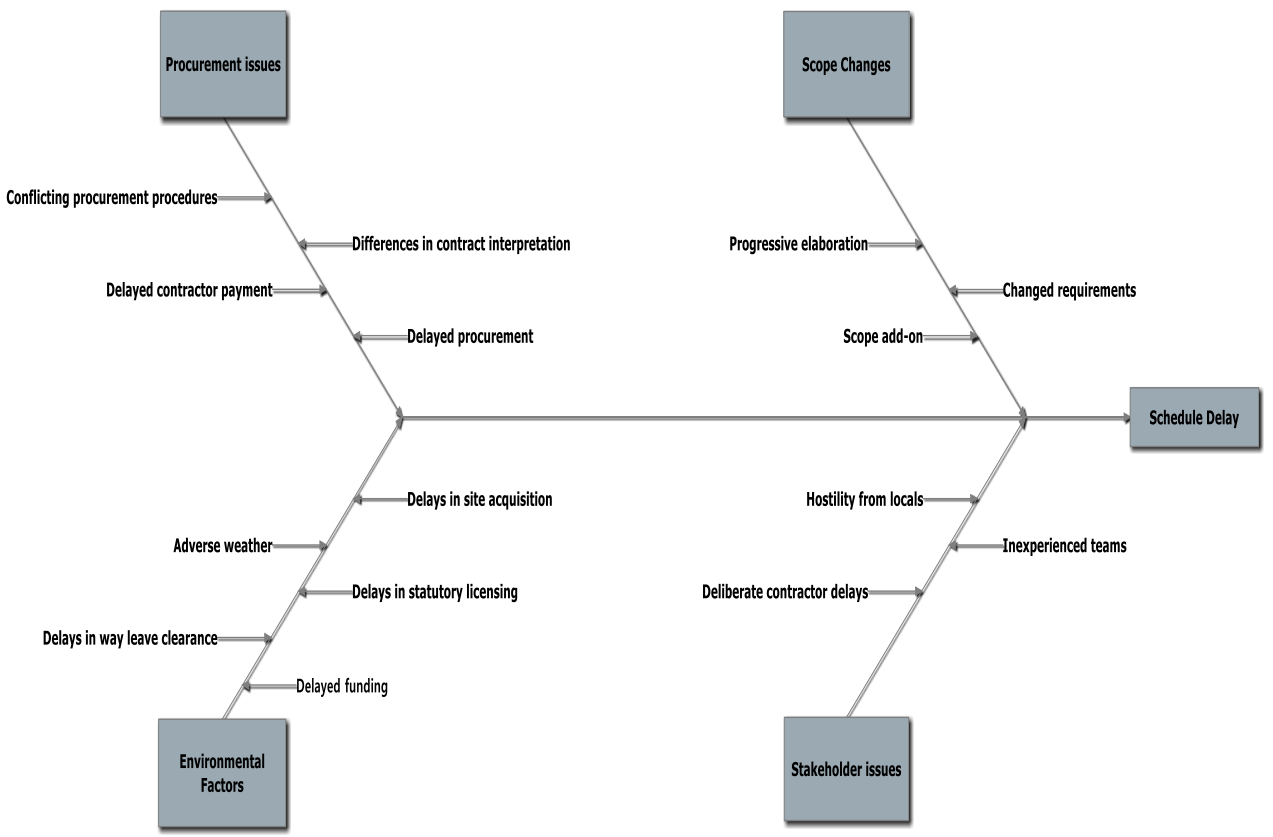

Figure 3: Major Causes of Schedule Delay

The process success score was determined by adding a score for project quality to the score for project efficiency. The quality score was based on the effect of changes (if any) to the scope baseline and was based on a scale of 1 (no or low impact) to 3 (high impact). The results showed that 6 megaprojects (22\%) underwent more than three scope changes, 13 megaprojects (48\%) underwent up to 3 scope changes while 8 megaprojects $(30 \%)$ did not undergo any scope change. Taking the maximum scores for efficiency and quality, the maximum possible score assigned to process success was 8 . Table 1 summarizes the process success scores.

Table 2 presents the project efficiency measures by sector of the projects. The results in this table show that the energy sector projects had the lowest relative cost performance $(\mathrm{CV}=0.42)$ but had the highest schedule $(\mathrm{CV}=0.19)$ and overall efficiency $(\mathrm{CV}=0.14)$ performances. The roads sector scored highest on cost performance $(\mathrm{CV}=0.16)$ while ports (air and sea) projects scored lowest in both schedule performance $(\mathrm{CV}=0.47)$ and overall efficiency $(\mathrm{CV}=0.31)$. 
Table 1: Process Success Scores of Public Infrastructural Megaprojects

Project

Project

Efficiency

Measures

CPI

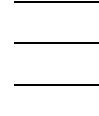

$1.00 \quad 1.50$

$0.84 \quad 1.00$

$1.00 \quad 0.80$

$0.98 \quad 0.78$

$\begin{array}{lll}5 & 0.81 & 0.6\end{array}$

6

$\begin{array}{lll}7 & 1.06 & 1.09\end{array}$

8

$\begin{array}{r}10 \\ 11 \\ \hline 12\end{array}$

$\begin{array}{r}12 \\ \hline 14 \\ \hline\end{array}$

\begin{tabular}{r}
1 \\
\hline 1 \\
17
\end{tabular}

18

19
2

22

23

$\begin{array}{r}25 \\ \hline 26\end{array}$

8

$0.86 \quad 0.24$

$\begin{array}{lll}10 & 1.00 & 0.56\end{array}$

$\begin{array}{lll}1 & 0.82 & 0.50\end{array}$

$\begin{array}{lll}12 & 1.17 & 0.75\end{array}$

$13 \quad 1.00 \quad 0.80$

$14 \quad 1.05 \quad 1.00$

$\begin{array}{lll}15 & 1.00 & 0.55\end{array}$

$\begin{array}{lll}17 & 0.92 & 0.90\end{array}$

Weighted Project

Efficiency (WPE)

$W P E=\frac{C P I+S P I}{2}$

Assigned

Efficiency

Assigned

Quality Score Score

Process

Success

Score

\begin{tabular}{lllllll}
18 & 0.90 & 0.54 & 0.72 & 3 & 3 & 6.00 \\
\hline 19 & 1.00 & 0.67 & 0.84 & 4 & 1 & 5.00 \\
20 & 0.88 & 0.75 & 0.82 & 4 & 3 & 7.00 \\
\hline 21 & 1.00 & 0.50 & 0.75 & 3 & 2 & 5.00 \\
\hline 22 & 1.00 & 0.71 & 0.86 & 4 & 2 & 6.00 \\
23 & 0.91 & 0.77 & 0.84 & 4 & 3 & 7.00 \\
\hline 24 & 1.04 & 0.46 & 0.75 & 3 & 1 & 4.00 \\
25 & 0.60 & 0.78 & 0.69 & 3 & 1 & 4.00 \\
26 & 0.65 & 0.42 & 0.54 & 2 & 2 & 4.00 \\
\hline 27 & 0.80 & 0.80 & 0.80 & 2 & 2 & 4.00
\end{tabular}

Descriptive Statistics:

\begin{tabular}{clll}
\hline Mean & 0.91 & 0.73 & 0.82 \\
\hline STDEV & 0.15 & 0.25 & 0.17 \\
\hline $\mathbf{C V}$ & 0.16 & 0.35 & 0.21
\end{tabular}

Table 2: Project Efficiency by Sector

SECTOR DESCRIPTIVE STATISTICS FOR EFFICIENCY MEASURES

\begin{tabular}{|c|c|c|c|c|c|c|c|c|c|}
\hline & \multicolumn{3}{|c|}{$C P I$} & \multicolumn{3}{|c|}{$S P I$} & \multicolumn{3}{|c|}{$W P E$} \\
\hline & MEAN & STDEV & $\mathrm{CV}$ & MEAN & STDEV & $\mathrm{CV}$ & MEAN & STDEV & $\mathrm{CV}$ \\
\hline $\begin{array}{l}\text { Ports } \\
n=9\end{array}$ & 0.85 & 0.17 & 0.20 & 0.79 & 0.37 & 0.47 & 0.80 & 0.25 & 0.31 \\
\hline $\begin{array}{l}\text { Energy } \\
n=7\end{array}$ & 0.97 & 0.41 & 0.42 & 0.78 & 0.15 & 0.19 & 0.88 & 0.12 & 0.14 \\
\hline $\begin{array}{c}\text { Roads } \\
n=11\end{array}$ & 0.91 & 0.15 & 0.16 & 0.66 & 0.19 & 0.28 & 0.79 & 0.12 & 0.15 \\
\hline
\end{tabular}




\section{Product and Organizational Success}

Product success measures the effectiveness of the project in delivering a product that meets the customer requirements, improves customer performance, and satisfies customer needs. To assess product success, project customers were asked to respond to a 5-item questionnaire of Likert-type scale. The product success scores were determined by averaging the responses with the highest score being 5 and the results interpreted based on a predetermined scale. The results indicate the projects had a mean product success score of 4.09 with a standard deviation of 0.94 .

Organizational success measures the interaction of process and product success to meet organizational objectives, maximize stakeholder value, and enhance organizational innovation capacity to deliver future projects. To assess organizational success, senior managers representing project sponsors were asked to respond to a 4-item questionnaire of Likerttype scale. The organizational success scores were determined by averaging the responses with the highest score being 5. The scores were then interpreted based on a predetermined scale. The results indicate that the projects had a mean organizational score of 4.39 with a standard deviation of 0.82 . Table 3 summarizes the process, product and organizational success scores.

\section{Composite Success Scores}

The composite success scores were obtained by taking the simple weighted average of the scores for process, product and organizational dimensions. With the highest score assigned to process, product and organizational dimensions being 8,5 , and 5 respectively, the highest possible mean composite score was therefore 6 . The composite success scores are shown in Table 3. Results of descriptive statistics for the scores of the three dimensions of project success show that the composite success scores had the lowest variability with $\mathrm{CV}=0.14$ while process and product success scores had the highest relative variability at $C V=0.24$ and $C V=0.23$, respectively. Project success results based on sector show that the energy sector projects had relatively the highest process success variability $(\mathrm{CV}=0.11)$ but had the lowest product $(\mathrm{CV}=0.45)$, organizational $(\mathrm{CV}=0.40)$ and composite $(\mathrm{CV}=0.28)$ success variability. The ports sector had the lowest relative process success $(\mathrm{CV}=0.29)$ but the highest relative product $(\mathrm{CV}=0.20)$, organizational $(\mathrm{CV}=0.13)$ and composite $(\mathrm{CV}=0.12)$ success. Table 4 provides a summary of project performance by sector. 
Table 3: Project Success Scores

Project Code Project Success Dimensional Scores Composite Success Score

\begin{tabular}{lcccc} 
& Process & Product & Organizational & \\
\hline 1 & 8.00 & 4.40 & 3.80 & 5.40 \\
\hline 2 & 7.00 & 4.40 & 4.00 & 5.13 \\
\hline 3 & 6.00 & 5.00 & 5.00 & 5.33 \\
\hline 4 & 6.00 & 5.00 & 5.00 & 5.33 \\
\hline 5 & 3.00 & 5.00 & 5.00 & 4.33 \\
\hline 6 & 4.00 & 4.00 & 4.00 & 4.00 \\
\hline 7 & 8.00 & 5.00 & 5.00 & 6.00 \\
\hline 8 & 6.00 & 3.60 & 3.80 & 4.47 \\
\hline 9 & 4.00 & 3.40 & 4.00 & 3.80 \\
\hline 10 & 5.00 & 3.80 & 4.00 & 4.27 \\
\hline 11 & 5.00 & 4.00 & 4.50 & 3.57 \\
\hline 12 & 7.00 & 1.20 & 2.50 & 5.33 \\
\hline 13 & 6.00 & 5.00 & 5.00 & 5.60 \\
\hline 14 & 7.00 & 5.00 & 4.80 & 5.13 \\
\hline 15 & 6.00 & 4.60 & 4.80 & 5.33 \\
\hline 16 & 7.00 & 4.00 & 5.00 & 3.67 \\
\hline 17 & 7.00 & 4.00 & 3.00 & 5.00 \\
\hline 18 & 6.00 & 2.00 & 2.00 & 5.00 \\
\hline 19 & 5.00 & 5.00 & 5.00 & 4.73 \\
\hline 20 & 7.00 & 3.00 & 5.00 & 4.93 \\
\hline 21 & 5.00 & 4.40 & 4.80 & 5.40 \\
\hline 22 & 6.00 & 4.00 & 4.80 & 4.00 \\
\hline 23 & 7.00 & 4.20 & 5.00 & 4.53 \\
\hline 24 & 4.00 & 3.00 & 5.00 &
\end{tabular}

Table 4: Project Success by Sector

Descriptive Statistics for Project Success Scores

\begin{tabular}{|c|c|c|c|c|c|c|c|c|c|c|c|c|}
\hline \multirow[t]{4}{*}{ Sector } & \multicolumn{12}{|c|}{ Descriptive Statistics for Project Success Scores } \\
\hline & \multicolumn{3}{|c|}{ Process } & \multicolumn{3}{|c|}{ Product } & \multicolumn{3}{|c|}{ Organizational } & \multicolumn{3}{|c|}{ Composite } \\
\hline & mea & stde & $\mathrm{cv}$ & mea & stde & $\mathrm{cv}$ & mea & stde & $\mathrm{cv}$ & mea & stde & $\mathrm{cv}$ \\
\hline & $\mathrm{n}$ & $\mathrm{v}$ & & $\mathrm{n}$ & $\mathrm{v}$ & & $\mathrm{n}$ & $\mathrm{v}$ & & $\mathrm{n}$ & $\mathrm{v}$ & \\
\hline Ports & 6.0 & 1.73 & 0.2 & 4.1 & 0.84 & 0.2 & 4.4 & 0.57 & 0.1 & 14.5 & 1.75 & 0.1 \\
\hline$n=9$ & & & 9 & & & 0 & & & 3 & & & 2 \\
\hline Energy & 6.1 & 0.69 & 0.1 & 3.8 & 1.71 & 0.4 & 3.9 & 1.53 & 0.4 & 13.2 & 3.64 & 0.2 \\
\hline$n=7$ & & & 1 & & & 5 & & & 0 & & & 8 \\
\hline Roads & 5.9 & 1.51 & 0.2 & 4.0 & 1.18 & 0.2 & 4.4 & 1.17 & 0.2 & 14.3 & 2.73 & 0.1 \\
\hline$n=11$ & & & 6 & & & 9 & & & 7 & & & 9 \\
\hline
\end{tabular}

This study also considered the relationship that exists among the three success measures. Pearson correlation was performed based on the performance data. The data was first checked for suitability conduct parametric tests such as regression and correlation analysis. This was done 
using normality test of skewness and kurtosis. Skewness involves the symmetry of distribution of the variable about its mean, whereas kurtosis involves the peakedness of probability distribution of a variable. The tests showed that both these coefficients were within the acceptable range.

The correlation results showed that at $99 \%$ confidence level, all the three dimensional measures of success had significant positive correlation with the overall composite success score but this correlation was much stronger between product dimension and overall composite score $(r=0.710)$. This was followed by the organizational success dimension ( $r=0.630)$. The correlation between the process success dimension and the composite project success was the lowest $(r=0.589)$. Further, the results show that there was a strong significant positive correlation between product success and organizational success $(r=0.709)$.

The correlation matrix is presented in Table 5.

Table 5: Correlation among Success Constructs

Process Success Product Success Org. Success Composite Success

\begin{tabular}{ccccc}
\hline $\begin{array}{c}\text { Process } \\
\text { Score }\end{array}$ & 1 & -.074 & -.164 & $.589^{* *}$ \\
\hline $\begin{array}{c}\text { Product } \\
\text { Score }\end{array}$ & -.074 & 1 & $.709^{* *}$ & $.710^{* *}$ \\
\hline Org. Score & -.164 & $.709^{* *}$ & 1 & $.630^{* *}$ \\
\hline $\begin{array}{c}\text { Composite } \\
\text { Success }\end{array}$ & $.589^{* *}$ & $.710^{* *}$ & $.630^{* *}$ & 1
\end{tabular}

\section{Linking Performance to Contractual Arrangements}

This study also assessed project performance by linking it to the contractual arrangements using a checklist that contained several statements regarding various project contractual arrangements and risk handling. The respondents were required to choose all the statements in the checklist that applied to their individual projects. The results show that of the 27 projects surveyed, $20(74.1 \%)$ projects utilized Fixed Price Contracts with $9(45 \%)$ of these utilizing a Firm Fixed Price/Lump sum (FFP) contract and 11 (55\%) projects utilizing Fixed Price with Economic Price Adjustment (FP-EPA) contract. One project $(3.7 \%)$ utilized a Cost-Plus Fixed/Percentage Fee $(\mathrm{CPFF} / \mathrm{PF})$ contract while $6(22.2 \%)$ projects utilized some form of Cost Contracts that involved re-measurement and ad-measurement based on initial estimates and Bill of Quantities respectively.

Table 6 presents the mean performance statistics of the megaprojects studied based on their contract types. 
Table 6: Project Success Based on Contract Types

\begin{tabular}{ccccc} 
Contract Type & No. of Projects & Mean Success & STDEV & CV \\
\hline FP-EPA & 11 & 4.86 & 0.79 & 0.162551 \\
\hline FFP & 9 & 4.3 & 1.01 & 0.234884 \\
\hline Remeasurable & 6 & 5.11 & 0.60 & 0.117417 \\
\hline CPF/PF & 1 & 5.4 & - & -
\end{tabular}

The results showed that with the exception of the 1 project that utilized a $\mathrm{CPF} / \mathrm{PF}$ contract, the projects that utilized cost contracts involving re-/ad-measurement had the highest mean success score at 5.11 points out of the possible 6.00 . These projects also recorded the lowest relative variability $(\mathrm{CV}=0.1174)$ in the individual mean success scores. Using the $\mathrm{CV}$ values as measures of riskiness in project success, projects using re-/ad-measurable contracts had less risk followed by those utilizing FP-EPA. The projects utilizing FFP recorded the highest risk in mean success.

Since contractual arrangements are usually a means of allocating cost and schedule risks, this study established that of the 11 megaprojects that utilized FPEA contracts, 6 (54.5\%) recorded cost overrun while 8 (72.7\%) experienced schedule slippage. Of the 9 projects that utilized FFP contracts, $4(44.4 \%)$ experience cost overruns while $8(88.9 \%)$ experienced schedule delay. Of the 6 projects that utilized re-/ad-measurable contracts, $4(66.7 \%)$ were delivered over budget with $5(83.3 \%)$ being delivered behind schedule. This study noted that for projects utilizing FFP contracts, project scope ended up being narrowed to fit into the budget. The CPF/PF contract project was delivered on budget but behind schedule. Table 7 summarizes cost and schedule performance based on types of contracts.

Table 7: Project Efficiency by Contract Type

\begin{tabular}{ccccc} 
Contract Type & \multicolumn{4}{c}{ Percentage of Projects Delivered With: } \\
\cline { 2 - 5 } & $C P I \geq 1$ & $C P I<1$ & $S P I \geq 1$ & $S P I<1$ \\
\hline FP-EPA & $45.5 \%$ & $54.5 \%$ & $27.3 \%$ & $72.7 \%$ \\
\hline FFP & $55.6 \%$ & $44.4 \%$ & $11.1 \%$ & $88.9 \%$ \\
\hline Remeasurable & $33.3 \%$ & $66.7 \%$ & $16.7 \%$ & $83.3 \%$ \\
\hline CPF/PF & $100 \%$ & - & - & $100 \%$
\end{tabular}

Barring the results of the project utilizing $\mathrm{CPF} / \mathrm{PF}$, the results in the table show that projects utilizing FFP contracts recorded the highest cost performance $(55.6 \%)$ but also recorded the lowest schedule performance $(88.9 \%)$. Projects that utilized FP-EPA contracts exhibited the second highest cost performance $(45.5 \%)$ but also the third lowest schedule performance (after $83.3 \%$ from re-/ad-measurable contract projects).

In $13(48.1 \%)$ of the surveyed projects the risk of schedule delay and cost overrun was contractually shared between the client and contractor. Of these projects, $3(11.1 \%)$ were delivered both on budget and on schedule, 5 
(18.5\%) were delivered on budget but behind schedule with the remaining 5 (18.5\%) delivered both with cost overrun and schedule delay. In 3 projects (11.1\%) the client assumed full responsibility for all the risks and insured against schedule delay and cost overrun. Of these, 1 (3.7\%) was delivered within budget and ahead of schedule, $1(3.7 \%)$ was delivered within budget but behind schedule with the remaining $1(3.7 \%)$ project delivered over budget but within schedule.

In 8 projects $(29.6 \%)$ the contractor assumed full responsibility for all the risks and provided guarantees. Of these projects, $3(11.1 \%)$ were delivered on budget, while none was delivered on schedule. In 3 projects (11.1\%) FIDIC conditions were used and schedule and cost risks were handled as they occurred. Of these projects, $1(3.7 \%)$ was delivered within budget while none was delivered within schedule. In summary, these results show that of the 24 megaprojects that either transferred risk to the contractor or shared it between the client and the contractor, 13 megaprojects (54.2\%) were delivered on budget while only 3 megaprojects (12.5\%) were delivered within schedule. Of the 3 megaprojects where the client assumed full responsibility for cost and schedule risk, $2(66.7 \%)$ of these met both cost and schedule objectives. Generally, the results show that megaprojects that either transferred risk to the contractor or shared risk between the contractor and client had better cost performance but poor schedule performance.

\section{Discussion}

This study used developments in project success theory to identify the broader measures of project success. The findings agree in part with the trending view that megaprojects are always delivered over budget, behind schedule, with benefit shortfalls, over and over again (Flyvbjerg, 2011). With $52 \%$ of the projects having been delivered overbudget and $82 \%$ having been delivered behind schedule, the "iron law of megaprojects" is partly confirmed. Whereas existing positive literature indicates that one out of ten infrastructural megaprojects is delivered on budget and one out of ten megaprojects is delivered on schedule (Flyvbjerg, 2014), this study only confirms this to the extent that $11 \%$ of the projects were delivered on schedule.

This study only considered the issue of benefits from a short run point of view because the project appraisal documents for these projects showed that the project benefits shall be realized gradually over a longer time horizon. The short run results for project benefits, however, seem to disagree with the view that megaprojects are delivered with benefit shortfalls. All the project and senior managers/sponsors surveyed strongly agreed that these projects enhanced their organizations' innovation capacity to deliver future projects, contributed to their organization's direct 
performance and maximized stakeholder value. Virtually all the megaprojects surveyed delivered products that were both "greenfield" and transformational. For instance, one of the projects surveyed at the KAA led to an increase in airport capacity from 50,000 passengers to 400,000 passengers; as a result of the several megaprojects at the Jomo Kenyatta International Airport, the airport rating has been enhanced and direct flights to and from the United States of America are now being considered; cargo handling and capacity at the port of Mombasa has significantly increased as a result of the Mombasa Port Modernization project; the road sector projects have been critical in reducing travel time and cost, and decongesting key town centres in Kenya; and more homes, schools and town centres have now been put on the national electricity grid. Some project products, such as the road network, are technological masterpieces that in themselves present aesthetic and economic value which puts Kenya ahead of other countries in the region.

The results showed that more of the variability in overall project efficiency is attributed to schedule performance than to cost performance and most projects that were delivered on or under budget experienced schedule delay. This is a key finding that may be pointing to the fact that most emphasis in megaproject management is directed on the cost element rather than to an integrated trade-off among cost, time and quality. Schedule delay affects both the quality of benefits and the project delivery cost. The longer the duration of the project the larger the cost overrun (Flyvbjerg et al., 2004).

The findings of this study on the main factors leading to schedule delay corroborate with the findings of Yang, Chu and Huang (2013). In their study, it was established that the most frequent cause of extended project duration is changed scope of work followed by weather, delayed inspection and acceptance from owner, and changed site conditions. On its part, this study identified way leave clearance and statutory requirements; scope addon and changes in project requirements; procurement issues and delays in payment, project team inexperience, stakeholder hostility and deliberate contractor delays; and delays in site acquisition and adverse weather; in that order, to be the main factors leading to schedule overrun.

The findings of this study also add to the growing view that operational excellence or process success does not necessarily imply project success (Baccarini, 1999; de Wit, 1988; Ika, 2009). For instance, when sectoral comparison was done, the ports sector had the lowest relative variability in process success $(\mathrm{CV}=0.29)$ but the highest relative variability in product $(\mathrm{CV}=0.20)$, organizational $(\mathrm{CV}=0.13)$ and composite $(\mathrm{CV}=0.12)$ success.

It is generally recognized in normative literature that the FFP is the most commonly used contract type (PMI, 2013). However, this study 
established that most infrastructural megaprojects utilized FP-EPA and the FFP was utilized by just one third of the projects surveyed. Given the sample size of this study, it may be difficult to draw a conclusion against the postulation of normative literature. The use of FP-EPA contractual arrangements is backed by the long term nature of the projects studied with the implementation of some spanning up to 6 years. With such longer implementation periods, it is likely that factors outside the control of the client or contractor, such as inflation and currency fluctuation, may adversely affect cost performance.

The use of Fixed Price contracts is usually a tactic of transferring the risk of cost overrun to the contractor. In the case of FFP contracts, the entire risk of cost overrun is actually transferred from the client to the contractor. In such cases, the contractors are usually careful not to eat into their profit margins. The results of this study agree with this practice given that a larger proportion of projects that utilized FFP contracts recorded the highest cost performance. This was followed by projects that utilized FP-EPA, which is a variation of FP contracts. Despite having recorded superior cost performance, projects that utilized FFP recorded the highest schedule slippage. This could mean that utilizing FFP contracts could be a zero sum game-since project management success must take into account both cost and schedule performance. It is noted that projects whose contracts included late delivery penalties actually delivered on schedule. This means that the use of FFP should be adjusted to include late delivery penalties if the objectives of both cost and schedule are to be achieved simultaneously.

The results indicate that none of the projects utilized contractual arrangements with incentives for accelerated cost or schedule delivery. Such pain/gain contracts would include Fixed Price Incentive Fee, Cost-Plus Incentive Fee or Cost-Plus Award Fee. The use of these types of contracts incentivizes the contractor for superior delivery of the pre-agreed performance metrics such as schedule and cost performance (PMI, 2013). As such, using these types of contracts is strongly associated with superior project performance (Brady \& Davis, 2014) since the parties involved in the project may prefer different actions because of their different risk preferences (Eisenhardt, 1989). Thus, the pain/gain contractual arrangements can be critical in solving the agency problem that characterizes most employer-contractor relationships (Jensen \& Meckling, 1976) on projects.

It is argued that transferring risk to the contractor (as in the use of Fixed Price contracts) offers no real protection for the client because the client is always accountable for cost, time, quality and safety (Brady \& Davis, 2014). The results of this study agree with this argument given that 2 out of the 3 projects in which the client assumed full responsibility for risk of cost overrun and schedule delay met their cost and schedule objectives. 
Thus, even though numbers are still small, the findings of this study could be pointing to the fact that behavior-oriented contracts lead to better results than outcome-based contracts.

\section{Conclusion and Recommendation}

The findings of this study have confirmed the global finding that infrastructure megaprojects are delivered over budget and behind schedule. However, the findings of this study did not confirm the view that these projects are delivered with benefit shortfalls. The short- run results of product and organizational success indicate that these projects have largely been a success. Given that megaprojects have a long payback period, it will probably be wise to conduct another study say 10 years later to ascertain the benefits of these projects. This will give a clearer picture of both product and organizational success. The findings of this study also lead to the conclusion that focusing on the project management process may not necessarily assure product and organizational success.

Infrastructure megaprojects have been shown to suffer more from schedule delay compared to cost overrun. This is attributed to the typical form of contractual arrangement used in the delivery of these projects. The results showed that almost all the 27 infrastructural megaprojects majorly utilized FFP and FP-EPA contracts. Even though these contract types lead to increased chances of delivery within budget, they carry with them an inherent risk of delivery behind schedule. However, in situations where such contracts included late delivery penalties schedule performance was greatly enhanced.

Projects in which the client assumed responsibility for cost and schedule risk had higher chances of meeting both cost and schedule objectives than those transferring or sharing this risk. By the projects' clients not assuming full responsibility for risk, they lose accountability and control over its triggers making the individual projects vulnerable. Transferring or sharing project risk increases chances of achieving cost objective but greatly reduces the chances of meeting schedule objective. The results showed that Scope changes, claims and penalties, currency fluctuation and inflation, and procurement issues are key factors that lead to cost overruns. Environmental factors, stakeholder issues, scope changes, and procurement issues were identified to be the main causes of schedule delay in infrastructural megaprojects.

In light of the findings of this study, it is recommended that public infrastructure megaproject sponsors and implementers adopt project structures that allow for innovation through the use of advanced technology. Such structures should encourage the use of competitive tendering and a preference for pain/gain contractual arrangements to accommodate the 
differences in risk preferences between the client and the contractor, and to minimize the incidences of agency problem among the various stakeholders.

\section{References:}

1. Atkinson, R. (1999). Project management: Cost, time and quality, two best guesses and a phenomenon, it is time to accept other success criteria. International Journal of Project Management, 17(6), 337-342.

2. Baccarini, D. (1999). The logical framework method of defining project success. Project Management Journal, 30(4), 25-32.

3. Bank Information Center (BIC). (2008). World Bank announces withdrawalfrom Chad- Cameroon Pipeline after early repayment.

Retrieved

from

http://www.bicusa.org/en/Article.3892.aspx (JS2).

4. Bannermann, P.L. (2008). Defining project success: A multilevel framework. In Proceedings of the PMI Research Conference (pp. 1-14). Newton Square, PA: Project Management Institute.

5. Brady, T., \& Davies, A. (2014). Managing Structural and Dynamic Complexity: A Tale of Two Projects. Project Management Journal, 45(4), 21-38.

6. Bryman, A., \& Bell, E. (2007). Business Research Methods ( $2^{\text {nd }}$ ed.). New York, United States: Oxford University Press Inc., p. 55.

7. Cao, Q., \& Hoffman, J.J. (2011). A case study approach for developing a project performance evaluation system. International Journal of Project Management, 29(2), 155-164.

8. Cooke-Davies, T. (2002). The real success factors on projects. International Journal of Project Management, 20(3), 185-190.

9. de Wit, A. (1988). Measurement of Project success. Project Management Journal, 6(3), 164- 170.

10. Flyvbjerg, B. (2014). What You Should Know About Mega Projects and Why: An Overview. Project Management Journal, 45(2), 6-17.

11. Flyvbjerg, B. (2011). Over budget, over time, over and over again: Managing major projects. In P.W. G. Morris, J.K. Pinto, \& J. Soderlund (Eds.), The Oxford Handbook of Project Management, pp. 321-344. England, Oxford: Oxford University Press.

12. Flyvbjerg, B., Holm, M.K.S., \& Buhl, S.L. (2004). What causes cost overrun in transport infrastructure projects? Transport Reviews, 24 (1), 3-18.

13. Gauthier, J-B., \& Ika, L.A. (2012). Foundations of Project Management Research: An Explicit and Six-facet Ontological Framework. Project Management Journal, 43(5), 5-23. 
14. Goldkuhl, G. (2012). Pragmatism vs interpretivism in qualitative information systems research. European Journal of Information Systems, 21(2), 135-146.

15. Government of Kenya. (2013). Second Medium Term Plan, 20132013. Kenya Vision 2030: Author.

16. Hirschman, A.O. (1995). Development projects observed ( $2^{\text {nd }}$ ed.). Washington, D.C: Brookings Institution.

17. Ika, L.A. (2009). Project success as a topic in project management journals. Project Management Journal, 40(4), 6-19.

18. International Rivers. (2012). Bujagali Dam, Uganda. Retrieved from http://www.internationalrivers.org/campaigns/bujagali-damuganda.

19. Hoegl, M., \& Gemuenden, H.G. (2001). Team work quality and the success of innovative projects: A theoretical concept and empirical evidence. Organization Science, 12(4), 435- 449.

20. Jensen, M., \& Meckling, W. (1976). Theory of the firm: Managerial behavior, agency costs, and ownership structure. Journal of Financial Economics, 3, 305-360.

21. Jugdev, K., \& Muller, R. (2005). A retrospective look at our evolving understanding of project success. Project Management Journal, 36(4), 19-31.

22. Jugdev, K., Thomas, J., \& Delisle, C.L. (2001). Rethinking Project Management: Old truths and new insights. Project Management Journal, 7(1), 36-43.

23. Kothari, R.C. (2006). Research Methodology: Methods \& Techniques (Revised $2^{\text {nd }}$ ed.). New Delhi, India: New Page.

24. Markus, M.L., \& Mao, J.Y. (2004). Participants in development and implementation-Updating an old tired concept for today's IS contexts. Journal of the Association for Information Systems, 5(11-12), 514-544.

25. McLeod, L., Doolin, B., \& MacDonell, G. S. (2012). A PerspectiveBased Understanding of Project Success. Project Management Journal, 43(5), 68-86.

26. Nassiuma, D.K. (2000). Survey Sampling: Theory and Methods. Nairobi: UoN Press.

27. Neuman, W.L. (2003). Social research methods: Qualitative and quantitative approaches, $\left(5^{\text {th }}\right.$ ed.). Upper Saddle River, NJ: Pearson Education.

28. Nunnally, J.C. (1978). Psychometric Theory ( $2^{\text {nd }}$ ed.) New York, NY: McGraw-Hill. 
29. Omonyo, B.A. (2015). Lectures in Project Monitoring and Evaluation for Professional Practitioners. Deutschland, Germany: LAP Lambert Academic Publishing. ISBN: 978- 3-659-62815-3.

30. Pinto, J. K., \& Slevin, D.P. (1988b). Critical Success Factors in Effective Project Implementation. In D. I. Cleland \& W.R. King (Eds.), Project Management Handbook, $\quad$ ( $2^{\text {nd }}$ ed., pp. 479-512). New York: Van Nostrand Reinhold.

31. Project Management Institute. (2013). A Guide to the Project Management Body of Knowledge $\quad\left(5^{\text {th }}\right.$ ed.). Pennsylvania, USA: Author.

32. Project Management Institute. (2011). Practice Standard for Project Estimating. Pennsylvania, USA: Author.

33. Shenhar, A. J., \& Dvir, D. (2007a). Reinventing project management: the diamond approach to successful growth and innovation. Boston, MA: Harvard Business School Press.

34. Shenhar, A.J., \& Dvir, D. (2007b). Project management researchThe challenge and opportunity. Project Management Journal, 38(2), 93-99.

35. Shenhar, A.J., Dvir, D., Levy, O., \& Maltz, A.C. (2001). Project success: A multidimensional strategic concept. Long Range Planning, 34(6), 699-725.

36. Shiferaw, A.T., \& Klakegg, O.J. (2011). Governance of public investment projects in Ethiopia. In Peer-reviewed proceedings of the $12^{\text {th }}$ annual international conference: challenges in the area of globalization (pp. 742-751). Edmonton. International Academy of African Business and Development IAABD).

37. Thomas, G., \& Fernandez, W. (2008). Success in IT projects: A matter of definition? International Journal of Project Management, 26(7), 733-742.

38. Wateridge, J. (1998). How can IS/IT projects be measured for success? International Journal of Project Management, 16(1), 5963.

39. Yang, J-B., Chu, M-Y., \& Huang, K-M. (2013). An Empirical Study of Schedule Delay Causes Based on Taiwan's Litigation Cases. Project Management Journal, 44(3), 21-31. 